\title{
Case Report \\ Granular Cell Tumor of Rectum: A Very Rare Entity
}

\author{
Tagore Sunkara, ${ }^{1}$ Savitha V. Nagaraj, ${ }^{1}$ and Vinaya Gaduputi ${ }^{2}$ \\ ${ }^{1}$ Department of Internal Medicine, The Brooklyn Hospital Center, Brooklyn, NY, USA \\ ${ }^{2}$ Department of Internal Medicine, SBH Health System, Bronx, NY, USA \\ Correspondence should be addressed to Tagore Sunkara; tagoresunkara@hotmail.com
}

Received 5 December 2016; Accepted 22 January 2017; Published 31 January 2017

Academic Editor: Hirotada Akiho

Copyright (c) 2017 Tagore Sunkara et al. This is an open access article distributed under the Creative Commons Attribution License, which permits unrestricted use, distribution, and reproduction in any medium, provided the original work is properly cited.

Granular cell tumors are predominantly benign, occurring more commonly in women, with about $10 \%$ developing in the gastrointestinal tract. Rectal location of this tumor is very rare. We herein report one such case of a 61-year-old man with granular cell tumor in the rectum who underwent endoscopic curative resection.

\section{Introduction}

Granular cell tumor (GCT), also known as granular cell myoblastoma or Abrikossoff tumor, was initially reported by Abrikossoff in 1926 [1]. It is a soft tissue neoplasm, arising from Schwann cells [2]. Predominantly a benign tumor, 1$2 \%$ of the cases are reported to be malignant [3-5]. It is more commonly seen in women and in the age group of $10-50$ years [6-8]. Granular cell tumor can arise in any body site and is most commonly seen in skin, subcutaneous tissue, oral cavity, and gastrointestinal tract $[8,9]$. About $10 \%$ of the tumors develop in the gastrointestinal tract with esophagus being the most common site and rectum being the rarest [10]. Although there are cases of granular cell tumor in various parts of the gastrointestinal system, there are very few reported cases of granular cell tumor in the rectum, especially in a male patient. We report a rare case of rectal granular cell tumor in a 61-yearold male patient.

\section{Case Report}

A 61-year-old man with medical comorbidities of coronary artery disease, congestive heart failure, hypertension, and dyslipidemia presented to the gastroenterology clinic for screening colonoscopy. Patient denied any gastrointestinal related complaints. Screening colonoscopy revealed good bowel preparation with a score of 8 on Boston Bowel Preparation Scale, a $1 \mathrm{~cm}$ serrated adenomatous polyp in the transverse colon that was removed with hot snare polypectomy, and a firm $4 \mathrm{~mm}$ nodule in the rectum that was removed with biopsy forceps (Figure 1). Biopsy of the rectal nodule revealed a granular cell tumor with positive periodic acid-Schiff (PAS) staining (Figure 2). Immunohistochemical staining for S-100 protein was positive as well (Figure 3). A subsequent rectal endoscopic ultrasound (EUS) confirmed complete removal of the tumor.

\section{Discussion}

Granular cell tumor (GCT) is a neoplasm of mesenchymal origin. It is thought to originate from the Schwann cells due to its positive staining for S-100, myelin, and myelin associated glycoprotein [2]. Histologically, GCT is comprised of large polygonal cells with eosinophilic cytoplasm containing PAS positive granules, abundant lysosomes, and small and uniform nuclei [11, 12]. It is more common in females compared to males and occurs predominantly in the age group of 10 50 years. It can occur in any part of the body but in the gastrointestinal tract, esophagus is the commonest location.

GCT commonly presents as a solitary mass, although some may present with multiple tumors in multiple locations [11]. In the gastrointestinal tract, tumor can present as a painless, nonulcerated nodule or a yellowish-gray sessile polyp with firm consistency. It is often found incidentally and needs to be differentiated from other submucosal tumors such as stromal tumor, carcinoid, steatoma, or smooth muscle tumor. On endoscopic ultrasound (EUS), GCT appears as small $(95 \%<2 \mathrm{~cm})$, hypoechoic, solid, homogenous tumor 


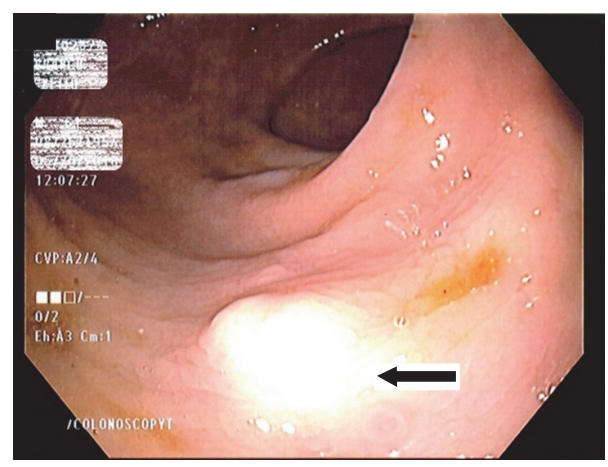

FIGURE 1: The $4 \mathrm{~mm}$ firm nodule visualized in rectum.

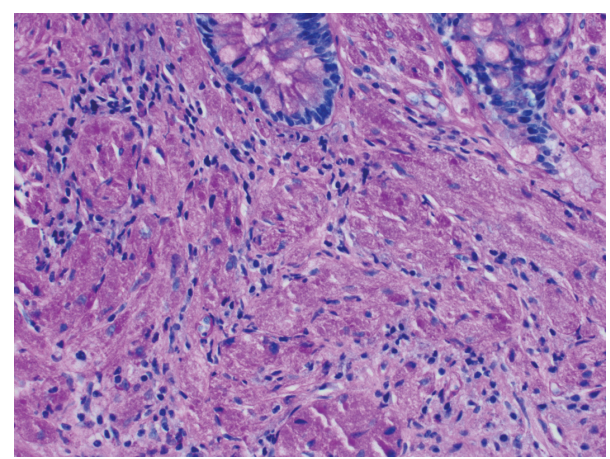

FIGURE 2: Rectal nodule biopsy (400x) revealing tumor cells arranged in sheets with small round-to-oval nuclei consistent with granular cell tumor on periodic acid-Schiff stain.

with invasion of the inner and/or outer layers of the gastrointestinal tract (mucosa/submucosa) [13]. GCT is commonly misdiagnosed as carcinoid tumor [14], with both tumors being mucosal or submucosal in location and having similar endoscopic findings. The carcinoid tumor arises from the enterochromaffin cells of the gastrointestinal tract and can be differentiated histologically and chemically from GCT [15].

GCT is mostly a benign tumor; however $2 \%$ of them can be malignant. A tumor greater than $3 \mathrm{~cm}$ or rapid tumor growth and ulceration raise a suspicion for malignant transformation [3, 4]. Fanburg Smith and colleagues proposed six criteria based on tumor histopathology to determine tumor malignancy and prognostic factors: cell necrosis, spindling, pleomorphism, increased mitotic activity ( $>2$ mitoses/10 HPF at 200x magnification), vesicular nuclei with large nucleoli, and high nuclear to cytoplasmic ratio. Neoplasms were classified as malignant if they met three or more of these criteria, atypical if they met one to two of these criteria, and benign if they displayed only focal pleomorphism and did not fulfill any other criteria [16].

Definitive diagnosis of GCT can be made by endoscopic biopsy and histopathological studies. The mainstay of treatment for a benign GCT, as was with our patient, is endoscopic resection. Different methods of endoscopic resections (mucosal and submucosal resections) are widely used and some resections with elastic band ligation have been reported [17]. For asymptomatic and smaller tumors,

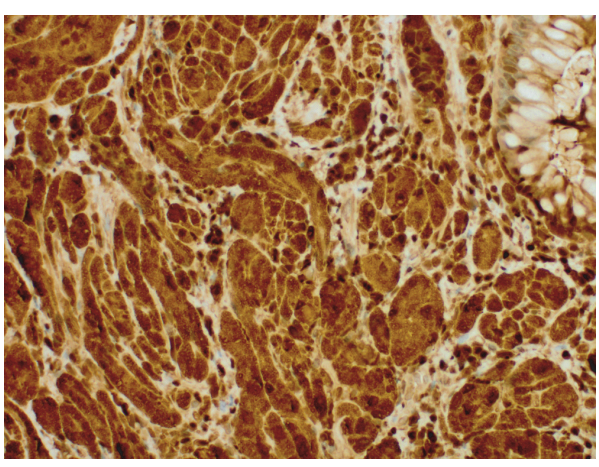

FIGURE 3: Biopsy revealing positive immunohistochemical staining for S-100 protein.

endoscopic surveillance may be sufficient [12]. Endoscopic ultrasound can be further performed to evaluate tumor invasion and assess complete tumor excision. Surgical resection with adequate margins can be reserved for large, malignant, and multifocal tumors invading the outer layers.

\section{Conclusion}

Granular cell tumors of gastrointestinal tract are rare entities with very few reports of rectal location. Although it is mostly a benign tumor, an astute clinician must be aware of possible malignant variants and the features of such lesions. It is equally important to differentiate granular cell tumor from other endoscopically similar mucosal and submucosal tumors of the rectum. Most gastrointestinal granular cell tumors are amenable for endoscopic resection which is often curative.

\section{Data Access}

Data relating to this case report is available from the corresponding author upon request.

\section{Consent}

Informed consent for participation was obtained from this patient.

\section{Disclosure}

This case report was exempted from the authors' Institutional Review Board as per its policy. An earlier version of this work was presented as a poster at ACG 2016 Annual Scientific Meeting and Postgraduate Course.

\section{Competing Interests}

None of the authors have any financial conflict of interests.

\section{Authors' Contributions}

All authors have made contributions to the article and have reviewed it before submission. 


\section{References}

[1] A. Abrikossoff, "Über Myome, ausgehend von der quergestreiften willkürlichen Muskulatur," Virchows Archiv für pathologische Anatomie und Physiologie und für klinische Medizin, vol. 260, no. 1, pp. 215-233, 1926.

[2] B. A. L. M. Santoni, F. E. S. Pinto, L. Machado et al., "Tumor de células granulares no canal anal: relato de caso e revisão de literatura," Revista Brasileira de Coloproctologia, vol. 26, no. 4, pp. 454-458, 2006.

[3] T. Khansur, L. Balducci, and M. Tavassoli, "Granular cell tumor: clinical spectrum of the benign and malignant entity," Cancer, vol. 60 , no. 2, pp. 220-222, 1987.

[4] H. Sonobe, J. Iwata, M. Furihata, T. Moriki, and Y. Ohtsuki, "Malignant granular cell tumor: report of a case and review of the literature," Pathology-Research and Practice, vol. 194, no. 7, pp. 507-513, 1998.

[5] A. Kataoka, M. Koike, K. Kuranuki, K. Wakayama, S. Yamada, and Y. Akasaka, "A case of malignant granular cell tumor arisen in the chest wall," Journal of Japan Surgical Association, vol. 66, no. 10, pp. 2403-2406, 2005.

[6] S. F. Vance and R. P. Hudson Jr., "Granular cell myoblastoma. Clinicopathologic study of forty-two patients," American Journal of Clinical Pathology, vol. 52, no. 2, pp. 208-211, 1969.

[7] N. G. Ordóñez, "Granular cell tumor: a review and update," Advances in Anatomic Pathology, vol. 6, no. 4, pp. 186-203, 1999.

[8] E. E. Lack, R. G. F. Worsham, M. D. Callihan et al., "Granular cell tumor: a clinicopathologic study of 110 patients," Journal of Surgical Oncology, vol. 13, no. 4, pp. 301-316, 1980.

[9] S. W. Weiss and J. R. Goldblum, Enzinger and Weiss's Soft Tissue Tumors, Mosby, St. Louis, Mo, USA, 5th edition, 2008.

[10] D.-K. Sohn, H.-S. Choi, Y.-S. Chang et al., "Granular cell tumor of colon: report of a case and review of literature," World Journal of Gastroenterology, vol. 10, no. 16, pp. 2452-2454, 2004.

[11] R. C. Llano, M. H. Gaitán, F. J. Banos, A. V. Hoyos, M. H. R. Vélez, and J. I. R. Restrepo, "Tumor de célulasgranularesen el tracto Gastrointestinal," Revista Colombiana de Gastroenterologia, vol. 21, no. 2, pp. 79-85, 2005.

[12] S. L. Narra, C. Tombazzi, V. Datta, and M. K. Ismail, "Granular cell tumor of the esophagus: report of five cases and review of the literature," American Journal of the Medical Sciences, vol. 335, no. 5, pp. 338-341, 2008.

[13] L. Palazzo, B. Landi, C. Cellier et al., "Endosonographic features of esophageal granular cell tumors," Endoscopy, vol. 29, no. 9, pp. 850-853, 1997.

[14] T. Nakanome, K. Yokoyama, H. Takeuchi et al., "Rectal granular-cell tumor difficult to distinguish from carcinoid tumor," Digestive Endoscopy, vol. 22, no. 4, pp. 325-328, 2010.

[15] M. K. Washington, L. H. Tang, J. Berlin et al., "Protocol for the examination of specimens from patients with neuroendocrine tumors (carcinoid tumors) of the colon and rectum," Archives of Pathology \& Laboratory Medicine, vol. 134, no. 2, pp. 176-180, 2010.

[16] J. C. Fanburg-Smith, J. M. Meis-Kindblom, R. Fante, and L.-G. Kindblom, "Malignant granular cell tumor of soft tissue. Diagnostic criteria and clinicopathologic correlation," American Journal of Surgical Pathology, vol. 22, no. 7, pp. 779-794, 1998.

[17] S. Sevilla Ribota, J. Pérez-Bedmar Delgado, J. J. Domínguez Cañete, A. M. Dotor de Lama, and M. Gómez-Rubio, "Endoscopic resection of rectal granular-cell tumor using elastic band ligation," Revista Española de Enfermedades Digestivas, vol. 108, no. 10, pp. 677-680, 2016. 


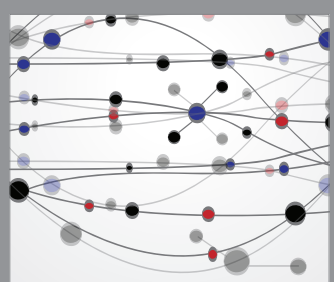

The Scientific World Journal
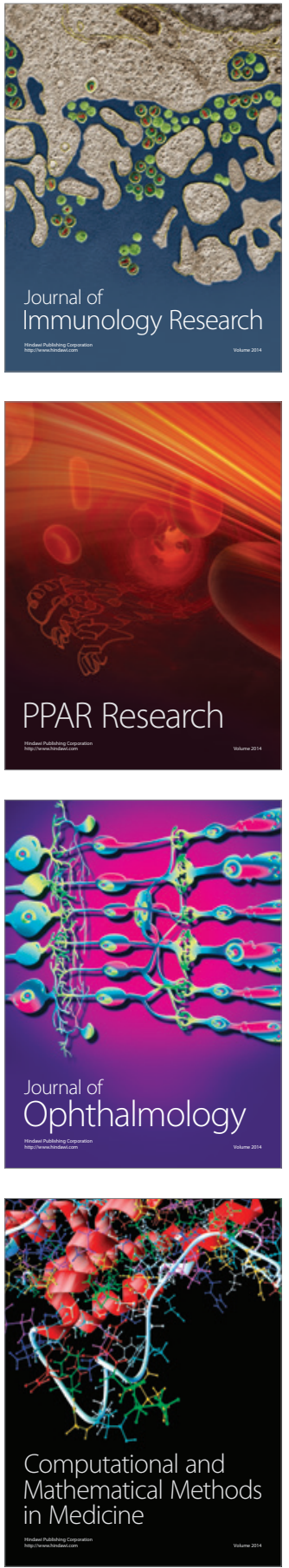

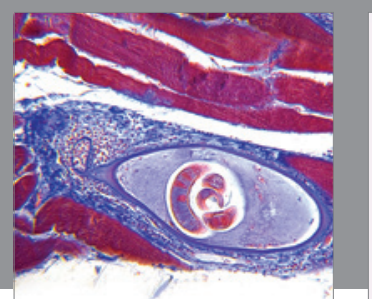

Gastroenterology Research and Practice
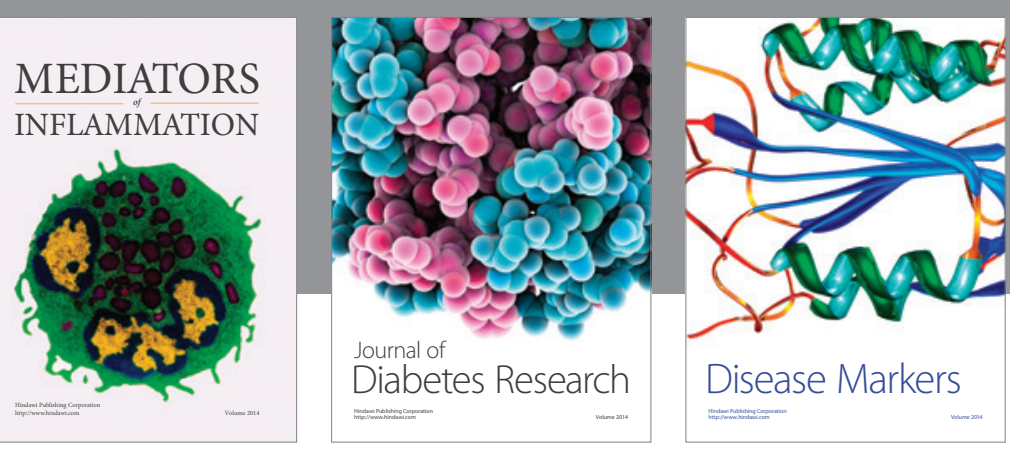

Disease Markers

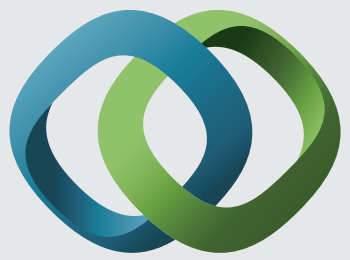

\section{Hindawi}

Submit your manuscripts at

https://www.hindawi.com
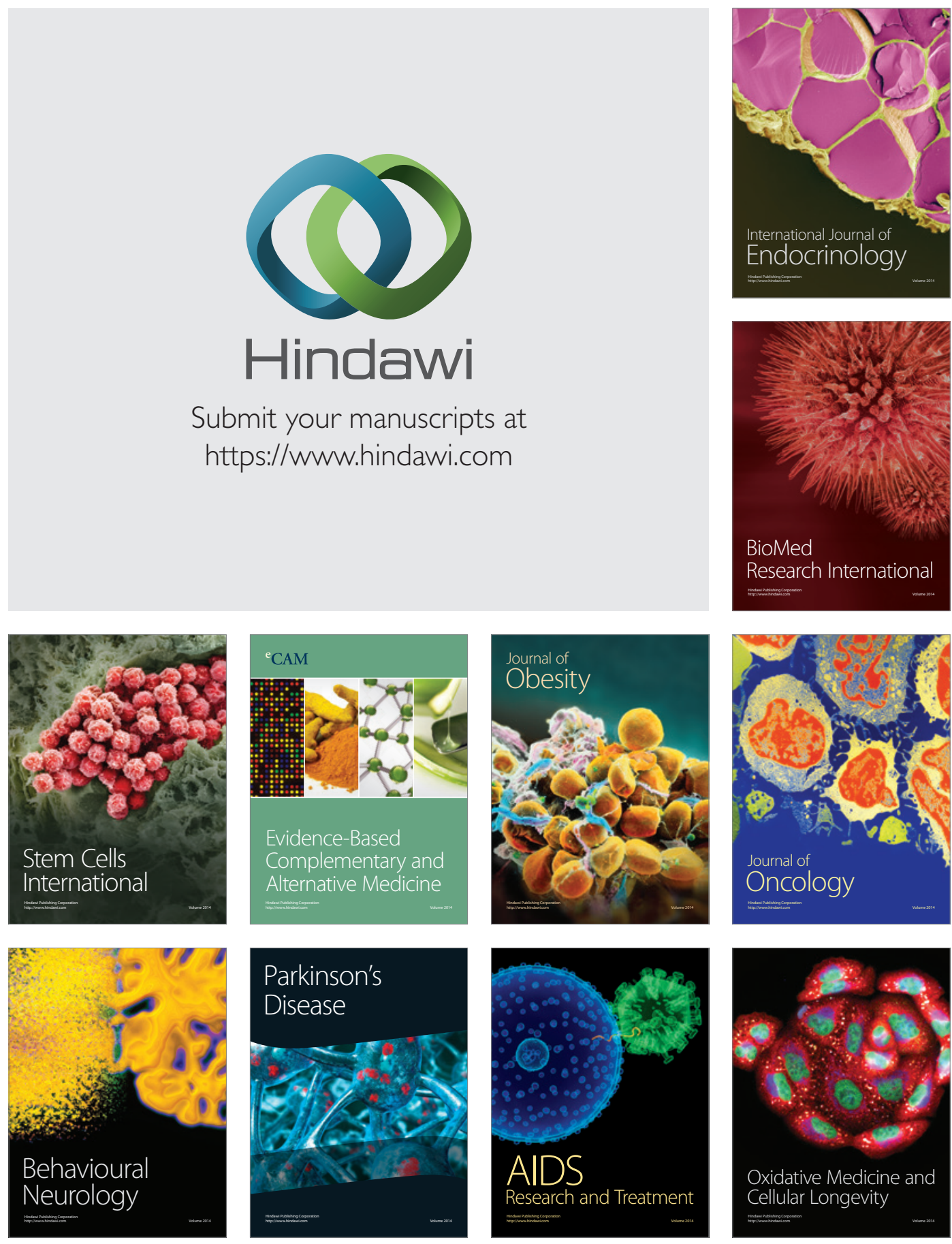